\title{
DEVELOPMENT OF MODERN BUSINESS PROCESSES AND OUTSOURCING ACTIVITIES
}

\author{
Svitlana Khalatur ${ }^{1}$, Igor Vinichenko ${ }^{2}$, Dmytro Volovyk ${ }^{3}$
}

\begin{abstract}
The purpose of the article is to study the key features of modern business processes and outsourcing. The subject-matter of the study is the methodological and conceptual foundations of the development process of modern business and outsourcing activities. Methodology. The research is based on a set of well-known general scientific and special methods of research in economics. In particular, the method of scientific abstraction, the method of systematic analysis, economic and mathematical modeling were used in the article. Conclusion. Many types of modern work can be outsourced. Thus, this will eventually lead to a confrontation between protected freelancers and freelancers whose employment is not regulated at the legislative level. The world is changing much faster, the labor market is undeniably affected when most jobs are simplified by technology; one of the consequences is a departure from the usual regulated labor relations and structures. The work environment and the environment are changing radically today. New forms of cooperation can take legal relations beyond legal regulation in those countries that fail to adapt their legislation in time to new rapidly evolving business strategies, which often lack the concept of territorial boundaries and mostly demand talent for effective solutions. With the help of constructed multifactor regression models, which are adequate to the available statistical and calculated data and have high degrees of significance of the estimated parameters, it is possible to predict changes in the simulated economic phenomenon as a result of changes in one or more factors. It should be noted that such models today are not sustainable in the long run, as in the Ukrainian and global economies, the external environment and its conditions change quite often. Therefore, in the future it is advisable to calculate new parameters of regression models based on the presented methods and make predictions according to the obtained data. In authors' opinion, the main reason for the increase in the share of outsourcing in Europe in the coming years is the strengthening of competition in the world market and the growth of the euro. It is believed that traditionally vertically integrated business processes will be broken into fragments and partially outsourced. This will allow European companies to increase their revenues and production volumes.
\end{abstract}

Key words: labor market, development of business strategies, information technology outsourcing, business process outsourcing; tool for optimizing the activities of the enterprise.

JEL Classification: E27, F62, 011

\section{Introduction}

Outsourcing as a business strategy is firmly integrated into international business, making changes to business processes in the market, both locally and globally, while maintaining a position of growth over the past decades. The use of external contractors (specialists in a particular field) helps to increase the competitiveness of their company in fast-growing industries, as well as

\footnotetext{
Corresponding author:

${ }^{1}$ Dnipro State Agrarian and Economic University, Ukraine.

E-mail: skhalatur@gmail.com

ORCID: https://orcid.org/0000-0001-8331-3341

ResearcherID: T-7645-2019

${ }^{2}$ Dnipro State Agrarian and Economic University, Ukraine.

E-mail: vinichenko.i.i@dsau.dp.ua

ORCID: https://orcid.org/0000-0002-9527-1625

${ }^{3}$ Dnipro State Agrarian and Economic University, Ukraine.

E-mail: volovykv@gmail.com

ORCID: https://orcid.org/0000-0001-6585-3328
}

gain access to the necessary professional resources with a certain reduction in their own costs to solve tasks.

In a market economy in a state of globalization, enterprises face a multiple increase in competition. In this regard, the problem of finding sources of support for economic efficiency becomes a priority. An important area of companies' adaptation to the changing 
market environment, with increased commercial risk and in the current crisis, is the use of outsourcing, that is a modern methodology for creating highly efficient organizations in conditions of fierce competition. The global dynamics of the development of commoditymoney relations is characterized by a clear focus on the production of services. In today's world, more than half of the GDP of advanced countries will be services. In the conditions of transformation of the world community, the service economy is an important vector of progressive development. The global trend in recent years is that outsourcing has become one of the main tools to increase business competitiveness. As a rule, it consolidates key management functions, which significantly reduces the cost of manufacturers to promote their own products.

The purpose of outsourcing as a management tool is to increase the market value of the enterprise by improving its performance, reducing costs and risks, increasing the competitiveness of products through the involvement of external contractors who specialize in performing certain, usually non-core for the company, production and economic functions. World practice has shown that it is profitable for a business to attract experienced specialized companies with highly qualified specialists to perform specific functions.

Therefore, there is an objective need for the formation and development of modern business processes to improve the efficiency of enterprises, which confirms the relevance of this study.

\section{Literature review}

Significant contribution to the study and disclosure of the essence of outsourcing as an element of the development strategy of business entities was made by scientists such as B.A. Anikin, M.Yu. Grygorak, H.H. Dumna, O.V. Zozulov, S.O. Kalendjian, I.D. Kotlyarov and others. Despite significant scientific developments, there are a number of issues that require further research, including comprehensive research on the theoretical foundations and methodological approaches to the development and adaptation of outsourcing business model to domestic business conditions. Given this, the issue of improving the effectiveness of enterprise development through the formation of an outsourcing business model is of particular importance and requires further research.

Thus, Olena Bilovodska, Nataliia Gaidabrus and Daria Ruban (2017) note that the modern economy is characterized by constant changes in the external micro and macro environment, accelerating the pace of technological progress; reduction of product life cycle; strengthening competition between domestic and foreign producers; changes in consumer tastes and preferences. World experience shows that such conditions exist for competing companies that provide a higher level of services. At the same time, there is a tendency to focus on the main types of activities of enterprises and the question of the transfer of certain functions of outsourcing is increasingly raised.

Dag Øivind Madsen (2017) in his research focused on the general structure of the popularity of international outsourcing, as the local popularity of outsourcing can differ significantly from the global pattern. Therefore, research can focus on the regional or country-specific trajectory of outsourcing popularity. Research has shown that outsourcing is closely linked to other management concepts and ideas.

Purpose. Given the relevance of the research topic, the purpose of the work is to study the key features of modern business processes and outsourcing.

\section{Research of world experience of development of modern business processes and outsourcing activity}

For the purposes of this article, outsourcing is defined as a set of measures aimed at transferring certain processes and functions to another organization that specializes professionally in the field of tasks and has a longer nature of interaction compared to one-time services used more situationally. By making a strategic decision on outsourcing, the customer gains access to the existing business process, individual systems and infrastructure of external companies, concentrating on conducting specialized activities in their company, increasing capacity with increasing market presence. The use of human resources is the basis of successful outsourcing in the world.

According to the latest report by Staffing Industry Analysts (SIA), the cost of crowdsourcing (when a wide range of people can be involved in solving tasks through information and communication technologies around the world) in the world ranged from 47 to 51 billion USD.

The Annual Global Services Location Index, formerly known as the Offshore Location Attractiveness Index, is a tool that helps companies understand and compare the factors that make countries attractive as potential locations for offshore services. It is analyzed the Global Service Location Index (GSLI) for 2016-2020. The global labor market for services is evolving as automation destroys low-skilled jobs and shifts the focus to more skilled jobs. The effort to find the right talent at the right price - anytime, anywhere - will continue and grow.

The Global Services Location Index rose from 50 countries in 2016 to 60 in 2021, indicating only how global the industry has become. Most locations have shifted in rankings over the years as competition has intensified and economies have developed. Central and Eastern Europe is a strong region where many of the best players now converge - Poland, Bulgaria, the Czech Republic and Romania in just a few places. In Table 1 the 
Table 1

Components of Global Services Location Index of European countries

\begin{tabular}{|c|c|c|c|c|c|c|c|c|c|c|c|}
\hline \multirow[b]{2}{*}{ Country } & \multicolumn{3}{|c|}{2017} & \multicolumn{4}{|c|}{2019} & \multicolumn{4}{|c|}{2021} \\
\hline & 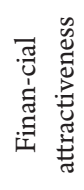 & 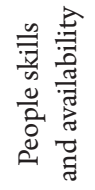 & 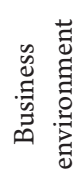 & 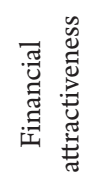 & 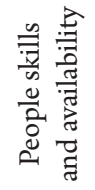 & 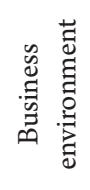 & 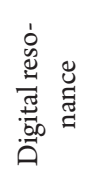 & 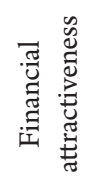 & 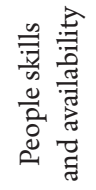 & 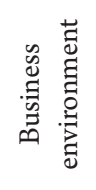 & 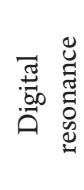 \\
\hline Poland & 2.63 & 1.38 & 1.68 & 2.05 & 1.11 & 1.56 & 0.63 & 2.15 & 1.18 & 1.58 & 0.72 \\
\hline Bulgaria & 2.99 & 0.95 & 1.61 & 2.47 & 0.73 & 1.61 & 0.61 & 2.52 & 0.77 & 1.64 & 0.66 \\
\hline \begin{tabular}{|l|} 
Czech \\
Republic
\end{tabular} & 2.44 & 1.17 & 1.87 & 1.95 & 0.93 & 1.68 & 0.64 & 1.91 & 0.99 & 1.75 & 0.66 \\
\hline Germany & 1.16 & 2.15 & 2.14 & 0.76 & 1.86 & 1.91 & 1.02 & 0.79 & 1.85 & 1.91 & 1.04 \\
\hline Romania & 2.84 & 1.13 & 1.49 & 2.29 & 0.92 & 1.46 & 0.58 & 2.27 & 0.97 & 1.52 & 0.60 \\
\hline \begin{tabular}{|l|} 
United \\
Kingdom
\end{tabular} & 1.03 & 2.26 & 1.12 & 0.85 & 1.84 & 1.95 & 1.14 & 0.85 & 1.93 & 2.08 & 1.11 \\
\hline Ukraine & 3.23 & 1.14 & 0.93 & 2.90 & 0.87 & 1.01 & 0.58 & 2.65 & 0.87 & 1.08 & 0.64 \\
\hline Estonia & 2.39 & 0.95 & 1.95 & 2.13 & 0.78 & 1.81 & 0.92 & 2.04 & 0.83 & 1.95 & 0.91 \\
\hline Hungary & 2.53 & 1.09 & 1.67 & 2.22 & 0.85 & 1.56 & 0.60 & 2.14 & 0.94 & 1.54 & 0.68 \\
\hline Latvia & 2.69 & 0.94 & 1.65 & 2.33 & 0.74 & 1.67 & 0.62 & 2.34 & 0.80 & 1.72 & 0.69 \\
\hline Lithuania & 2.73 & 0.92 & 1.64 & 2.46 & 0.72 & 1.63 & 0.70 & 2.23 & 0.77 & 1.70 & 0.71 \\
\hline Portugal & 1.91 & 1.32 & 1.86 & 1.66 & 1.15 & 1.70 & 0.83 & 1.83 & 1.23 & 1.79 & 0.74 \\
\hline Turkey & 2.32 & 1.45 & 1.32 & 1.96 & 1.28 & 1.22 & 0.59 & 2.07 & 1.41 & 1.32 & 0.66 \\
\hline Slovakia & 2.32 & 1.00 & 1.69 & 2.04 & 0.78 & 1.69 & 0.62 & 2.02 & 0.82 & 1.67 & 0.66 \\
\hline France & 0.85 & 2.04 & 2.04 & 0.56 & 1.72 & 1.81 & 0.93 & 0.65 & 1.82 & 1.95 & 0.99 \\
\hline Spain & 1.09 & 1.84 & 1.86 & 1.00 & 1.51 & 1.61 & 0.88 & 1.13 & 1.57 & 1.83 & 0.88 \\
\hline Ireland & 0.50 & 1.66 & 2.04 & 0.57 & 1.37 & 1.86 & 0.92 & 0.48 & 1.42 & 1.98 & 0.97 \\
\hline
\end{tabular}

Source: compiled by authors based on A.T. Kearney Global Services Location Index data

components of A.T. Kearney Global Services Location Index of European countries are analyzed.

The development of the information society, the transition to priority scientific, technological and innovative development, the introduction of IT in all spheres of life of the state determined the emergence and development of new management technologies, such as outsourcing, outstaffing and others. Thus, there is a formation of innovation infrastructure, which determines the new quality of economic growth. The strategy of raising the productive forces through science and education increases the opportunities of large countries in scientific and technological innovation and improves the quality of the workforce.

In developed countries, outsourcing has become an important tool to ensure the competitive advantage of the enterprise. In Ukraine, this process is not so fast, but with the intensification of competition in the domestic market, the development of integration processes, more and more companies recognize its benefits and feasibility. The use of outsourcing is aimed at stabilizing the development of the enterprise, effective use of its internal potential, increasing flexibility and adaptability to changes in the market environment, finding new market opportunities, increasing the company's ability to innovate. Outsourcing stimulates the development of competition, undermining the oligopolistic and monopolistic structures of the world economy, enabling new entrants to enter the markets, eliminating the dominant position of individual companies in the market. On the other hand, large companies, possessing powerful resources, are constantly increasing their share of international markets, expanding geographical boundaries, putting more and more production under control, i.e., strengthening the function of controlling the economies of countries. More and more companies are switching to the so-called "international network model of organization of activities", which helps increase efficiency, reduce financial, production, technological and political risks.

Thus, traditional vertically integrated Western companies are gradually being replaced by transnational horizontal network structures. And we are talking about the formation of a geoplanetary production and functional network. The form of the company's presence in the country's economy is the creation of so-called "service centers" owned by TNCs, but geographically located in countries with cheap labor. They integrate scientific and technical, production potentials of different countries, provide round-theclock work in their service centers located around the world, thus working to constantly reduce costs. Transnational service companies, offering outsourcing services, compete with national outsourcing companies, 
offering lower prices. They are ready to minimize their profits in order to conquer markets. At the same time, they incur quite high costs due to high salaries, which are offered to specialists, enticing them to national outsourcing companies. In general, outsourcing is a new form of development of industrial and economic relations, focused on the integration and replacement of commodity relations with production and functional. Thus, we can talk about the formation of a mobile adaptive international and geoplanetary network that accelerates the development of economic globalization in modern society.

Institutional support of business process outsourcing (its content) is the actions of the government aimed at establishing institutions (norms, rules, restrictions) and determining the order of their observance, aimed at achieving the goals and objectives set by the government in cooperation with outsourcing entities business processes (or in the absence of such interaction). The task of institutional support for the long-term development of business process outsourcing is to carry out reforms, respect the rights and freedoms of economic entities, and actually promote the development of market institutions.

Institutional support for business process outsourcing is achieved not directly, but through relevant organizations: public authorities, corporate and other business structures, state enterprises. Organizational aspects are important as those that are closely related to the tradition of neo-institutionalism and Coase's theory that organizations (firms) are created to save transaction costs. Thus, attention should be paid to the problems of forming effective organizational structures in the real sector of Ukraine's economy, adequate to today's challenges, the problem of interaction between government institutions and market agents, as well as the institutional aspects of business process outsourcing.

In Table 2, it is analyzed the dynamics of A.T. Kearney Global Services Location Index of European countries. In 2017, Ukraine was ranked 24th in the TOP-25 of the Global Services Location Index, GSLI. In 2021, Ukraine moved to $42 \mathrm{nd}$ place. The outsourcing potential of each of the 55 countries participating in the ranking is assessed by 38 indicators, comparing the financial attractiveness, professionalism and availability of the necessary human resources, as well as the business environment.

Countries in the Global Service Location Index were selected on the basis of corporate data, current remote service activities, and government initiatives to promote the industry. They were evaluated in four main categories: financial attractiveness, people's skills, business environment and digital resonance (Table 1).

In Figure 1, it is analyzed the size of the global market for outsourcing services for 2000-2019.

The size of the business process outsourcing market in 2020 was estimated at 232.32 billion USD, and from 2021 to 2028 the annual growth rate (CAGR) is expected to be $8.5 \%$. The agility of the business to survive the ever-changing dynamics of the business and ways to increase efficiency, while reducing operating costs and emphasizing core competencies, are mostly important. Moreover, organizations are increasingly focused on reducing the cost of doing business to access global resources to meet the growing needs of the industry. As a result, several organizations around the world are taking advantage of business process outsourcing

Table 2

The dynamics of Global Services Location Index of European countries

\begin{tabular}{|l|c|c|c|c|c|c|}
\hline \multirow{2}{*}{ Country } & \multicolumn{2}{|c|}{2017} & \multicolumn{2}{c|}{2019} & \multicolumn{2}{c|}{2021} \\
\cline { 2 - 7 } & Rank & Index & Rank & Index & Rank & Index \\
\hline Poland & 12 & 5.69 & 24 & 5.35 & 14 & 5.63 \\
\hline Bulgaria & 15 & 5.55 & 17 & 5.42 & 54 & 5.59 \\
\hline Czech Republic & 16 & 5.48 & 33 & 5.21 & 5.31 \\
\hline Germany & 17 & 5.46 & 15 & 5.25 & 32 & 5.59 \\
\hline Romania & 18 & 5.45 & 28 & 5.79 & 8 & 5.36 \\
\hline United Kingdom & 19 & 5.41 & 8 & 5.36 & 42 & 5.97 \\
\hline Ukraine & 24 & 5.31 & 20 & 5.64 & 12 & 5.73 \\
\hline Estonia & 25 & 5.30 & 12 & 5.24 & 37 & 5.30 \\
\hline Hungary & 26 & 5.30 & 31 & 5.36 & 20 & 5.55 \\
\hline Latvia & 28 & 5.29 & 21 & 5.52 & 30 & 5.41 \\
\hline Lithuania & 29 & 5.29 & 16 & 5.33 & 18 & 5.59 \\
\hline Portugal & 37 & 5.09 & 26 & 5.06 & 26 & 5.46 \\
\hline Turkey & 38 & 5.09 & 39 & 5.12 & 44 & 5.17 \\
\hline Slovakia & 42 & 5.01 & 35 & 5.02 & 29 & 5.41 \\
\hline France & 44 & 4.93 & 41 & 5.00 & 28 & 5.41 \\
\hline Spain & 49 & 4.79 & 42 & 4.72 & 51 & 4.85 \\
\hline Ireland & 53 & 4.20 & 47 & & & \\
\hline
\end{tabular}

Source: compiled by authors based on A.T. Kearney Global Services Location Index data 


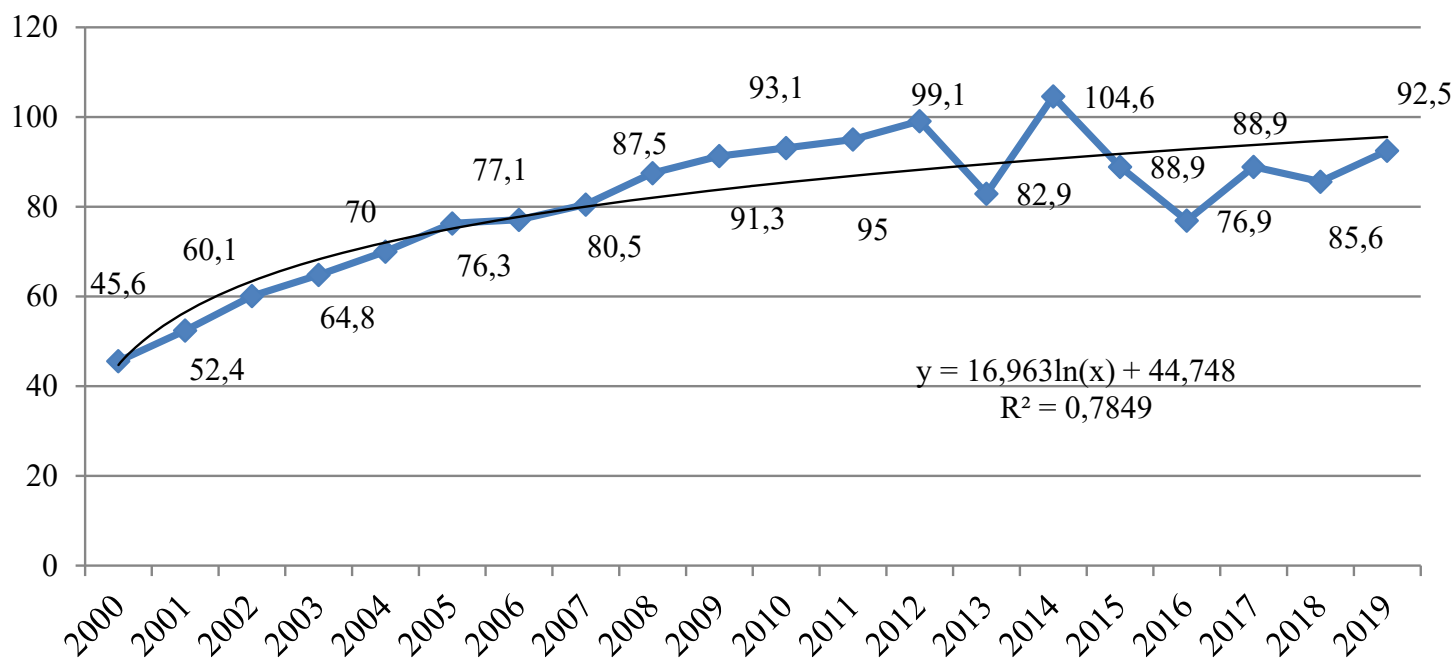

Figure 1. The size of the global market for outsourcing services for 2000-2019, billion USD

Source: compiled by authors based on statista's data

(BPO) services and focusing on core competencies, thus creating ways to grow the market.

The versatility of business process outsourcing services is driving market growth as several enduse industries, including banking, financial services, healthcare and manufacturing, use these services to some extent. Benefits such as reduced operating costs and increased efficiency of support functions, such as customer service, encourage the adoption of business process outsourcing services. Offering enhanced business relationships, business process outsourcing services also provide reliable, up-to-date and round-theclock support for important business processes. Shifting the focus from monopolistic business strategies to the joint burden of business culture determines the demand for outsourcing business processes for further success and improved results.

Technological advances in various fields, such as automated robotic processes, machine learning, social media browsing and big data analysis, portend future market growth prospects. Increasing the advantage of cloud technologies and other automation methods helps stimulate the market. Moreover, such factors, the improvement of cloud infrastructure and the rapid introduction of process automation into business functions also contribute to market growth. In addition, it is expected that increasing the level of acceptance of business processes as a service for streamlining the numerous workflows through their automated planning will stimulate market growth over the forecast period.

Business process outsourcing service providers take advantage of cloud computing to reduce the time required to process business processes that require large amounts of data. Cloud computing in outsourcing business process leads to an improved data processing workflow in a shorter turnaround time. In addition, thanks to the Internet and the continuous improvement of the network infrastructure around the world, a way has been paved to place applications in the cloud instead of complex infrastructure prone to downtime. Moreover, several market players are involved in integrating cloud computing into the service portfolio to improve the outsourcing process.

It is expected that the growing number of government initiatives implemented to promote the introduction of cloud technologies will work well in the market. It is also expected that the growth of government investments around the world in the field of cloud computing will contribute to the overall growth of the market, thereby increasing the demand for business process outsourcing solutions.

Business process outsourcing involves outsourcing various non-core back-office and front-office functions, including IT services, call center operations, financial services and recruitment services. Outsourcing these features allows companies to reduce their operating costs and focus on their core competencies. It is expected that the growing demand for reducing operating costs for non-core activities and increasing attention to core competencies in several end-use verticals will increase demand for such services.

The influence of many factors on the output variable can be described by a linear model:

$$
\mathrm{Y}=\mathrm{a}_{0}+\mathrm{a}_{1} x_{1}+a_{2} x_{2}+a_{3} x_{3}+\ldots+a_{m} x_{m}+U,
$$

where $\mathrm{Y}$ is the exact actual values of the studied (dependent, explained) variable, indicator or regression; $\mathrm{x}_{1}, \mathrm{x}_{2}, \mathrm{x}_{\mathrm{m}}$, are independent (explanatory) variables, factors or regressors; $a_{0}, a_{1}, a_{2}, \ldots$, am are unknown model parameters; $\mathrm{U}$ is the random component of the regression equation, $\mathrm{m}$ is the number of factors in the model.

Function (1) is linear with respect to the independent variables and parameters of the model, but it is the linearity by parameters that is more significant because 
Table 3

Indicators of the business environment of studied European countries on average for 2001-2020

\begin{tabular}{|l|c|c|c|c|c|c|c|}
\hline \multicolumn{1}{|c|}{ Country } & $\begin{array}{c}\text { Foreign direct } \\
\text { investment, } \\
\text { net inflows } \\
\text { (\% of GDP) }\end{array}$ & $\begin{array}{c}\text { Foreign direct } \\
\text { investment, } \\
\text { net outflows } \\
\text { (\% of GDP) }\end{array}$ & $\begin{array}{c}\text { GDP growth } \\
\text { (annual \%) }\end{array}$ & $\begin{array}{c}\text { Gini index } \\
\text { (World Bank } \\
\text { estimate) }\end{array}$ & $\begin{array}{c}\text { Gross capital } \\
\text { formation } \\
\text { (\% of GDP) }\end{array}$ & $\begin{array}{c}\text { Inflation, } \\
\text { GDP deflator } \\
\text { (annual \%) }\end{array}$ & $\begin{array}{c}\text { Tax } \\
\text { payments } \\
\text { (number) }\end{array}$ \\
\hline Poland & 3.25 & 1.03 & 3.79 & 33.17 & 20.84 & 2.21 & 23.80 \\
\hline Bulgaria & 8.36 & 0.90 & 3.59 & 36.93 & 24.07 & 4.26 & 16.33 \\
\hline Czech Republic & 4.81 & 1.92 & 2.85 & 26.18 & 28.39 & 1.88 & 10.60 \\
\hline Germany & 2.03 & 3.10 & 1.27 & 30.88 & 20.57 & 1.36 & 10.40 \\
\hline Romania & 3.74 & 0.22 & 4.13 & 36.31 & 25.50 & 10.40 & 62.67 \\
\hline United Kingdom & 4.10 & 3.37 & 1.76 & 34.51 & 17.22 & 1.99 & 8.07 \\
\hline Ukraine & 3.80 & 0.22 & 2.43 & 26.46 & 22.38 & 15.78 & 72.73 \\
\hline Estonia & 8.09 & 3.69 & 3.78 & 32.76 & 29.42 & 4.55 & 7.67 \\
\hline Hungary & 9.80 & 7.63 & 2.56 & 29.87 & 23.68 & 4.32 & 12.33 \\
\hline Latvia & 3.45 & 0.77 & 3.73 & 35.83 & 28.03 & 4.63 & 8.47 \\
\hline Lithuania & 3.14 & 1.17 & 4.22 & 35.83 & 21.34 & 2.92 & 11.07 \\
\hline Portugal & 3.92 & 2.22 & 0.73 & 36.28 & 20.34 & 1.99 & 7.67 \\
\hline Turkey & 1.66 & 0.32 & 4.83 & 40.77 & 26.74 & 13.69 & 10.00 \\
\hline Slovakia & 4.14 & 1.15 & 3.93 & 26.49 & 25.14 & 1.96 & 22.20 \\
\hline France & 2.05 & 3.32 & 1.29 & 32.07 & 22.71 & 1.34 & 11.40 \\
\hline Spain & 2.92 & 4.01 & 1.67 & 34.64 & 23.47 & 1.83 & 8.80 \\
\hline Ireland & 20.21 & 16.51 & 4.76 & 32.54 & 26.17 & 1.69 & 9.00 \\
\hline
\end{tabular}

Source: compiled by authors based on World Bank data

it is related to the methods of estimating parameters. The random component is the resultant action of all uncontrolled random factors that cause deviations of the real values of the studied indicator from the analytical ones (calculated on the basis of the selected regression dependence). Linear relationships do not exhaust all possible forms of dependence between indicators. Therefore, in the study of a particular economic phenomenon, the priority is to find the most accurate analytical form of describing the statistical relationship between its indicators. Some form of dependence must have an appropriate economic justification. If the type of dependence is difficult to establish, then for the first approximation to the model still choose a linear dependence.

The usual mathematical approach to solving problems is to separate specific classes of problems or to reduce problems to a certain class and to apply appropriate methods of solving them. Since the study of linear functions has indisputable advantages over other classes of functions, nonlinear functions try to reduce primarily to linear ones. Thus, the subject of our research will be a generalized multifactor linear regression model (1).

Based on the available data, it is necessary to build a linear multifactor regression model of the relationship Global Services Location Index from Foreign direct investment, net inflows ( $\%$ of GDP) - x1; Foreign direct investment, net outflows (\% of GDP) - x2; GDP growth (annual\%) - x3; Gini index (World Bank estimate) $\mathrm{x} 4$; Gross capital formation (\% of GDP) - x5; Inflation, GDP deflator (annual\%) - x6; Tax payments (number) $\mathrm{x} 7$ according to the table. 3 .
The calculations of the model were performed using the functions of the EXCEL package. Then, the regression equation ( 1 ) has the form:

$$
\begin{aligned}
& \mathrm{Y}=10,2+0,34 x_{1}-0,24 x_{2}+0,46 x_{3}+ \\
& +0,21 x_{4}+0,57 x_{5}+0,24 x_{6}+0,18 x_{7} .
\end{aligned}
$$

After creating a regression model, it is necessary to assess its practical significance. Residual variance $\sigma_{\varepsilon_{i}}^{2}=50,52$. The percentage deviation of individual sample values varies from $0.07 \%$ to $32.31 \%$. The average approximation error for the regression equation as a whole is $\mathrm{k}=10.03 \%$.

Auxiliary values are to calculate the multiple correlation coefficient. The value of the multiple correlation coefficient $\mathrm{R}=0.9181$ indicates a close linear correlation with factor features, as well as a satisfactory agreement between theoretical and actual data. Regression and variance analyzes of linear regression were performed using the option "Regression" of the EXCEL package (Table 4).

Table 4

Results of regression analysis

\begin{tabular}{|l|c|}
\hline \multicolumn{2}{|c|}{ CONCLUSION } \\
\hline \multicolumn{2}{|c|}{ Regression statistics } \\
\hline Multiple R & 0.918075435 \\
\hline R-square & 0.842862505 \\
\hline Normalized R-square & 0.797966078 \\
\hline Standard error & 7.088771776 \\
\hline Observations & 119 \\
\hline
\end{tabular}

Source: authors' calculations 
Table 5

The results of the econometric analysis of the dependence of the Global Services Location Index on the studied factors

\begin{tabular}{|l|c|c|c|c|c|c|}
\hline \multicolumn{1}{|c|}{ Indices } & Coefficients & Standard error & t-statistic & P-Value & Lower 95\% & Upper 95\% \\
\hline Y-intersection & 11.29995504 & 9.46554875 & 1.1937981 & 0.271439 & -1.08251 & 33.6824211 \\
\hline Variable X1 & 0.34186688 & 7.39399643 & 5.3298466 & 0.001087 & 1.924843 & 56.8928901 \\
\hline Variable X2 & -0.243771887 & 8.20071100 & 0.7962446 & 0.452043 & -2.86182 & 25.921372 \\
\hline Variable X3 & 0.460574832 & 6.91742914 & 1.6378239 & 0.127864 & -2.86182 & 23.978546 \\
\hline Variable X4 & 0.214562751 & 8.09174632 & 0.5367823 & 0.934106 & 2.59873 & 24.906753 \\
\hline Variable X 5 & 0.576734582 & 7.34109763 & 1.8243561 & 0.256381 & 4.98746 & 23.678231 \\
\hline Variable X 6 & 0.246278391 & 6.45823901 & 0.5247186 & 0.053461 & 1.45673 & 25.983561 \\
\hline Variable X 7 & 0.182134832 & 8.27814538 & 0.8745632 & 0.108493 & 2.345671 & 23.68732 \\
\hline
\end{tabular}

Source: authors' calculations

From the tables it is found the critical value of the Student's criterion $t_{\mathrm{cr}}=2.365$;

$$
\Delta R=2,365 \frac{1-0,9191^{2}}{\sqrt{17-2-1}}=0,14 .
$$

The confidence interval for the multiple correlation coefficient has the form $0.9181-0.14 \leq \mathrm{R} \leq 0.9181+0.14$. Since the multiple correlation coefficient cannot be more than 1 , the interval takes the form $0.78 \leq \mathrm{R} \leq 1$. With an error of $5 \%$, it can be said that the actual correlation coefficient is not less than 0.78 .

The coefficient of determination $\mathrm{R}^{2}=0.8429$ shows that $84.29 \%$ of the variance of the indicator can be explained using the model of dependence on $\mathrm{i}$.

The coefficient of F-statistics is equal to $\mathrm{F}=0.8429$ / $(1-0.8429)^{*}((17-2-1) / 2)=18.77$. The critical value at $\alpha=0.05$ will be Fcr $(17 ; 7 ; 0.05)=4.74$. Since F $>$ Fcr, the constructed model can be considered adequate.

The meaningful value of the parameters of the found model is as follows:

- if the factor $\mathrm{x} 1$ changes by its unit of measurement, the average will change by a $1=0.34$ units of its measurement, provided that other factors remain unchanged;

- similarly, if the factor $\mathrm{x} 2$ changes per unit of its measurement, the indicator will change by a $=0.24$ units of its measurement, provided that other factors remain unchanged;

- if the factor $\mathrm{x} 3$ changes by its unit of measurement, the indicator will change by a $3=0.46$ units of its measurement, provided that other factors remain unchanged;

- if the factor $\mathrm{x} 4$ changes by its unit of measurement, the indicator will change by a $=0.21$ units of its measurement, provided that other factors remain unchanged;

- if the factor $x 5$ changes to the unit of its measurement, the indicator will change to a5 $=0.57$ units of its measurement, provided that other factors remain unchanged;

- if the factor $\mathrm{x} 6$ changes by its unit of measurement, the indicator will change by a $6=0.24$ units of its measurement, provided that other factors remain unchanged;

- if the factor $x 7$ changes per unit of its measurement, the indicator will change by a $7=0.18$ units of its measurement, provided that other factors remain unchanged;

Thus, the change in Foreign direct investment, net inflows, GDP growth, Gross capital formation, Inflation by $1 \%$ will lead to a change in the Global Services Location Index by 0.34, 0.46; 057; 0.24 in that direction; a change in Foreign direct investment, net outflows by $1 \%$ will change the Global Services Location Index in the opposite direction by 0.24 ; and changing the Gini index (World Bank estimate) and Tax payments (number) by 1 will change the Global Services Location Index by 0.21 and 0.18 , respectively.

\section{Conclusions}

Many types of modern work can be outsourced. Thus, this will eventually lead to a confrontation between protected freelancers and freelancers whose employment is not regulated at the legislative level. The world is changing much faster, the labor market is undeniably affected when most jobs are simplified by technology; one of the consequences is a departure from the usual regulated labor relations and structures. The work environment and the environment are changing radically today. New forms of cooperation can take legal relations beyond legal regulation in those countries that fail to adapt their legislation in time to new rapidly evolving business strategies, which often lack the concept of territorial boundaries and mostly demand talent for effective solutions.

With the help of constructed multifactor regression models, which are adequate to the available statistical and calculated data and have high degrees of significance of the estimated parameters, it is possible to predict changes in the simulated economic phenomenon as a result of changes in one or more factors. It should be noted that such models today are not sustainable in the long run, as in the Ukrainian and global economies, the external environment and 
its conditions change quite often. Therefore, in the future it is advisable to calculate new parameters of regression models based on the presented methods and make predictions according to the obtained data.

In our opinion, the main reason for the increase in the share of offshore outsourcing in Europe in the coming years is the strengthening of competition in the world market and the growth of the euro. It is believed that traditionally vertically integrated business processes will be broken into fragments and partially outsourced. This will allow European companies to increase their revenues and production volumes. In the segment where companies with foreign capital operate, the most common is the long-term offshore outsourcing business model.
According to the results of research, it can be concluded that the use of outsourcing model of doing business in domestic enterprises can significantly increase the efficiency of their activities and open fundamentally new opportunities for mutually beneficial cooperation, significantly strengthen their competitiveness in today's economic environment, as this business model resources for the main objectives of the business by delegating certain functions to third parties that provide outsourcing services and reducing the cost of functions outsourced to the outsourcing company. In addition, the outsourcing business model helps to gain access to resources or new technologies that are missing or insufficient in the enterprise, as well as minimizing the level of responsibility and risk for performing a particular function.

\section{References:}

Bilovodska, O., Gaidabrus, N., \& Ruban, D. (2017). An analytical study on logistics outsourcing impact on logistical service quality in supply chains (case study: industrial enterprises of Sumy region). Problems and Perspectives in Management, 15(3), 201-211. doi: 10.21511/ppm.15(3-1).2017.04

Dag Øivind Madsen (2017). Examining the popularity trajectory of outsourcing as a management concept. Problems and Perspectives in Management, 15(2-1), 178-196. doi: 10.21511/ppm.15(2-1).2017.02

Deloitte's Global Outsourcing Survey (2021). Available at: https://www2.deloitte.com/global/en.html (accessed 24 May 2021)

Gewald, H., \& Schäfer, L. (2017). Quo vadis outsourcing? A view from practice. Journal of Global Operations and Strategic Sourcing, 10(1), 2-17.

Grand View Research (2021), Available at: https://www.grandviewresearch.com/industry-analysis/businessprocess-outsourcing-bpo-market (accessed 01 May 2021)

Hrušecká, D., Macurová, L., Juřičková, E., \& Kozáková, L. (2015). The Analysis of the Use of Outsourcing Services in Logistics by Czech Manufacturing Companies". Journal of Competitiveness, 7 (3), 50-61.

Khalatur, S. (2013). Features of the functioning mechanism of the investment market in Ukraine. Bulletin of Poltava State Agrarian Academy, 4, 121-124. (in Ukrainian)

Khalatur, S., Trokhymets, O., \& Karamushka, O. (2020). Conceptual basis of tax policy formation in the globalization conditions. Baltic Journal of Economic Studies, 6(2), 81-92. doi: https://doi.org/10.30525/2256-0742/2020-6-2-81-92

Khalatur, S., Khaminich, S., Dubovych, O., Budko, O., \& Karamushka, O. (2020). Multiple system of innovation investment decisions adoption with synergetic approach usage. Entrepreneurship and Sustainability, 7(4), 27452763. doi: http://doi.org/10.9770/jesi.2020.7.4(12).

Khalatur, S., Stachowiak, Z., Zhylenko, K., Honcharenko, O., \& Khalatur, O. (2019). Financial instruments and innovations in business environment: European countries and Ukraine. Investment Management and Financial Innovations, 16(3), 275-291. doi: http://dx.doi.org/10.21511/imfi.16(3).2019.25

Khalatur, S. (2017). Important provisions for the development of agriculture of Ukraine. Baltic Journal of Economic Studies, 3(2), 147-154. doi: https://doi.org/10.30525/2256-0742/2017-3-2-147-154.

The Outsourcing Institute, USA (2021). Available at: http://www.outsourcing.com (accessed 25 May 2021)

Global Outsourcing market 2021. Available at: https://www.statista.com/statistics/189788/global-outsourcingmarket-size (accessed 31 May 2021)

Vasylieva, N. (2019) Improvement of Agricultural Management: Functional Comparative Approach. Montenegrin Journal of Economics, 15(1), 227-238. doi: 10.14254/1800-5845/2019.15-1.17

Velychko, O., Velychko, L., \& Ramanauskas, J. (2016). Transformation and development of production-logistics enterprises in Ukrainian agrarian economy. Management Theory and Studies for Rural Business and Infrastructure Development, 38(1), 70-87. Available at: https://publons.com/publon/19531873/

World Bank (2021). World Development Indicators 2021, World Bank. Available at: https://data.worldbank.org/ indicator (accessed 11 May 2021) 